\title{
STRATEGIC PLANNING OF ORGANIZING KERMAN CITY DISTRICT TWO WITH WALKABLE APPROACH
}

\author{
Mr.Amirali Mohseni \\ M.A Student in Urban Planning, Kerman Branch, Islamic Azad University, Kerman, Iran \\ rmohseni89@gmail.com \\ Dr. Nima Jahanbin \\ Assistant professor, Faculty of Architecture, Art and Planning \\ Kerman Branch, Islamic Azad University. \\ jahanbin.nima@gmail.com
}

\begin{abstract}
In Iran, transportation especially using private cars has been rapidly increased and a major part of streets is occupied by automobiles and each day their number is raising and streets have turned to a place special to automobiles passage and the culture of driving has dominated walkable and traditional culture. Kerman city in Iran has had a noble and classic culture but today it is rapidly moving towards industrialization and getting away from human scale. Unfortunately, at the present time Kerman city doesn't have walking axle and walkable culture has decreased. In this study, we seek a way to promote walkable culture with walkable approach. On this same basis, primary information was collected by library- documentary method and then by field survey and preparing required data, sidewalk routes of Kerman city district 2 were analyzed and the following results were obtained with the aid of AHP SWOT model. Regarding the evaluation of external and internal factors and also SWOT model, the final score relating to internal factor evaluation is equal to 2.986 and final score of external factors evaluation is 3.257. The situation of acquired scores from matrixes of evaluating internal and external factors is in the first quarter (aggressive strategy) as follows. So, regarding the above explanations, the dominant strategy in walkability of Kerman city district 2 is of aggressive type.
\end{abstract}

Keywords: $A H P$, SWOT, strategic planning, Kerman city

\section{INTRODUCTION}

By emergence of modernistic urban planning, the emphasis on cities development for facilitating cars movement leaded to insignificance of suitable urban spaces (including square and street) for walking and the street as an urban space and the place of social interactions was less noticed (Jepson \& Edward,2010 ). Urban spaces have formed for supplying social and mental needs (Berke et.al, 2010). All citizens in their daily activities at least walk a part of their route and pedestrian needs are ignored in most urban spaces (Talen \& Koschinsky, 2012). Many present planning methods especially in the third world don't meet human physical, mental and spiritual needs and have ignored human scale and position. Therefore, regarding that many current problems are due to car oriented views instead of human oriented attitudes in cities, changing the planning attitude towards a human oriented and walkable city is essential.

Among other problems of third world urban society is low social interactions in the society daily life that walkability plans a principled collection that the capability of pedestrian movement and acceptance of neighboring units and creating a friendly environment for passengers are among its important points. Of course, the aim is not omitting automobile from everyday life, but it is tried that pedestrians despite presence of cars in the city feel safe and secure and satisfied. Necessarily, people close contact and affront with each other is quite noticed in walkability. On the other hand, existence of cars pollution, traffic, lack of welfare and safety feeling have been created due to increasing usage 
of cars in everyday life that in walkability by exploring effective environmental features, this has been realized that physical, traffic and data network features have a considerable role in walking frequency and non-use of cars and the quarter environmental quality and its social dimensions have a significant role in walking. Also, lack of suitable places for social interactions like past has caused reduction of attachment feeling and social interactions and increasing usage of cars and pedestrian- orienting and pavement have been considered insignificant ( Bentli et.al, 2013:7).

On the other hand, $25 \%$ of city area is constituted from ways and unfortunately a major portion of this path has been occupied by cars. Especially, in undeveloped countries this matter is clearly observed. The main reason of this matter is lack of accurate planning, high costs and inattention to walking culture.

In Iran, transportation especially using private cars has rapidly increased and a major part of streets is occupied by cars and everyday their number is raising and streets are allocated to a place special to cars passage and driving culture has dominated walking and traditional culture. Kerman is one of big cities of Iran which has had a noble and ancient culture in the past but today it is rapidly moving to industrialization and getting away from human scale. Unfortunately, at the present time Kerman doesn't have a pedestrian axle and walkable culture has decreased. In other words, inattention to pavements and lack of pedestrian axle in Kerman has caused reduction of suitable pavements and lack of pedestrian axles has caused reduction of social interactions of inhabitants. On this basis, authors of this article seek a way for promoting walkable culture with walkability approach.

\section{IMPLICATION AND BACKGROUND OF WALKABILITY}

Walkability includes creating streets or spaces free from riding traffic. London road in Norwich was the first street in England which was closed on traffic and became walkable in 1957. When in 1971, the first public place in Sidney of Austria was assigned to mere usage of passengers, Leoport ( the local politician responsible for this issue) who called himself as minister of passengers, always emphasized on telling this positive aspect that the street was opened for passengers, not that it was closed on cars traffic ( Cowan, 2852005).

As SpeiRegen, theorist of 1960s, considers many of without car city streets dead and spiritless, mentions that if cars interfere with passengers' free footwork, it will be problematic and if cars move with low speed and passing traffic reduces to its lowest possible level, in crowded urban centers both could be allowed to be present. But, now extreme intersections have been designed in urban crowded centers so that maximum car traffic flows to be supplied. As a result, this matter compels that passenger for long and annoying waiting. SpeiRegen considers the solution of this problem in designing pedestrian safe islands, reducing traffic speed, increasing pedestrian passages and facilitating their use (SpeiRegen, 1960, 72).

In the field of attention to walks and their role in cities, as yet many studies have been performed by various scholars in the world and in Iran that the results of some of them are as follows:

Table 1. A sample from walk experiences out of Iran

\begin{tabular}{|l|l|l|l}
\hline item & scholar name & research year & the study results \\
\hline 1 & Morris & 1995 & $\begin{array}{l}\text { Because of streets crowd and continuous } \\
\text { contacts of cars and passengers, wagons } \\
\text { passage inside city during day hours except } \\
\text { governmental wagons was prevented. }\end{array}$ \\
\hline 2 & Morris & 1995 & $\begin{array}{l}\text { in 1987, London considered some preparations } \\
\text { for carts traffic , for suitable carts and wagons } \\
\text { quartering besides people }\end{array}$ \\
\hline
\end{tabular}




\begin{tabular}{|c|c|c|c|}
\hline 3 & $\begin{array}{l}\text { Almostad } \\
\text { American planner } \\
\text { and architecture }\end{array}$ & 1958 & $\begin{array}{l}\text { designing of New York central park with the } \\
\text { aim of separating passengers from cars }\end{array}$ \\
\hline 4 & Francis Tybaldz & & $\begin{array}{l}\text { Public eras as the most important part of cities } \\
\text { and urban environment that in such eras the } \\
\text { greatest contact and relation and interaction } \\
\text { occur between men. }\end{array}$ \\
\hline 5 & $\begin{array}{l}\text { England } \\
\text { conference }\end{array}$ & 2000 & $\begin{array}{l}\text { the first conference by Walk } 21 \text { group with the } \\
\text { slogan of towards walking in } 21^{\text {st }} \text { century }\end{array}$ \\
\hline 6 & $\begin{array}{l}\text { Austria } \\
\text { conference }\end{array}$ & 2001 & $\begin{array}{l}2^{\text {nd }} \text { conference by Walk21 with the slogan of } \\
\text { towards livable cities }\end{array}$ \\
\hline 7 & Spain conference & 2002 & $\begin{array}{l}3^{\text {rd }} \text { conference by Walk } 21 \text { group with slogan } \\
\text { of equality and environment }\end{array}$ \\
\hline 8 & $\begin{array}{l}\text { American } \\
\text { conference }\end{array}$ & 2003 & $\begin{array}{l}4^{\text {th }} \text { conference by Walk } 21 \text { group with the } \\
\text { slogan of health }\end{array}$ \\
\hline 9 & $\begin{array}{l}\text { Denmark } \\
\text { conference }\end{array}$ & 2004 & $\begin{array}{l}5^{\text {th }} \text { conference by Walk } 21 \text { with slogan of cities } \\
\text { for people }\end{array}$ \\
\hline 10 & Swiss conference & 2005 & $\begin{array}{l}6^{\text {th }} \text { conference by Walk } 21 \text { with slogan of } \\
\text { environments with walking capability }\end{array}$ \\
\hline 11 & $\begin{array}{l}\text { Melbourne } \\
\text { conference }\end{array}$ & 2006 & $\begin{array}{l}7^{\text {th }} \text { conference by Walk } 21 \text { with slogan of daily } \\
\text { walking culture }\end{array}$ \\
\hline 12 & $\begin{array}{l}\text { Canada } \\
\text { conference }\end{array}$ & 2007 & $\begin{array}{l}8^{\text {th }} \text { conference by Walk } 21 \text { with slogan of } \\
\text { passengers priority }\end{array}$ \\
\hline 13 & Moazen et.al & 2006 & introduced 4 indexes of walkability in quarters \\
\hline 14 & $\begin{array}{l}\text { Ganizade, } \\
\text { Mohammadali }\end{array}$ & 2001 & $\begin{array}{l}\text { measured for organizing and designing } \\
\text { passenger movement in urban quarter of } \\
\text { Ekhtiarieh Tehran }\end{array}$ \\
\hline 15 & Habibi, Mitra & 2003 & $\begin{array}{l}\text { examined and analyzed significance of walks } \\
\text { and their role in urban central space of Tehran }\end{array}$ \\
\hline 16 & Rafian et.al & 2005 & $\begin{array}{l}\text { In an article under the title of urban spaces: } \\
\text { emphasizes on qualitative revising and } \\
\text { evaluating and revising necessity in public } \\
\text { spaces especially in modern urbanism trends. } \\
\text { the results obtained from this study is that } \\
\text { promotion of urban public spaces quality is } \\
\text { necessary for creating social capital and } \\
\text { enforcement of a society }\end{array}$ \\
\hline
\end{tabular}

Table2- Sample of walks experiences inside Iran 


\begin{tabular}{|l|l|l|l|l}
\hline item & sidewalk name & city & year & aim \\
\hline 1 & Shahriyar & Tabriz & 1994 & $\begin{array}{l}\text { a place for purchase and } \\
\text { recreation }\end{array}$ \\
\hline 3 & Zand & Chiraz & $1997-1999$ & $\begin{array}{l}\text { facilitating the region } \\
\text { passing traffic }\end{array}$ \\
\hline 4 & Janat & Shiraz & - & $\begin{array}{l}\text { uses variety and using } \\
\text { symbolic elements }\end{array}$ \\
\hline 5 & Tarbiat & Mashhad & 1999 & $\begin{array}{l}\text { transfer of riding traffic } \\
\text { load, suitable flooring, } \\
\text { variety in urban furniture, } \\
\text { improvement of visual } \\
\text { aspect }\end{array}$ \\
\hline 6 & Marvi Alley & Tabriz & 1992 & $\begin{array}{l}\text { omitting heavy traffic and } \\
\text { commercial-recreational } \\
\text { performance }\end{array}$ \\
\hline 7 & Panzdah Khordad & Tehran & $2011-2012$ & $\begin{array}{l}\text { facilitating citizens traffic } \\
\text { and promoting security/ } \\
\text { improvement of visage } \\
\text { and physical organizing of } \\
\text { façade and wall }\end{array}$ \\
\hline & & & $\begin{array}{l}\text { constructing sustainable } \\
\text { urban furniture against } \\
\text { stroke and pressure/ } \\
\text { designing urban } \\
\text { infrastructures }\end{array}$ \\
\hline
\end{tabular}

\section{SITUATION OF STUDY RANGE}

Kerman city extent is more than $74.3 \mathrm{~km}^{2}$. Kerman city population has been 384991 persons according to census 1996 and in census performed in 1996, this city population has reached 496684 persons that the population growth in this year has been $2.81 \%$ and in 2011 this city population has evaluated 600000 persons. Generally, the residential density of Kerman city is low and it is almost half of the standard density of other cities of Iran (Naghdinasab, 2011). 

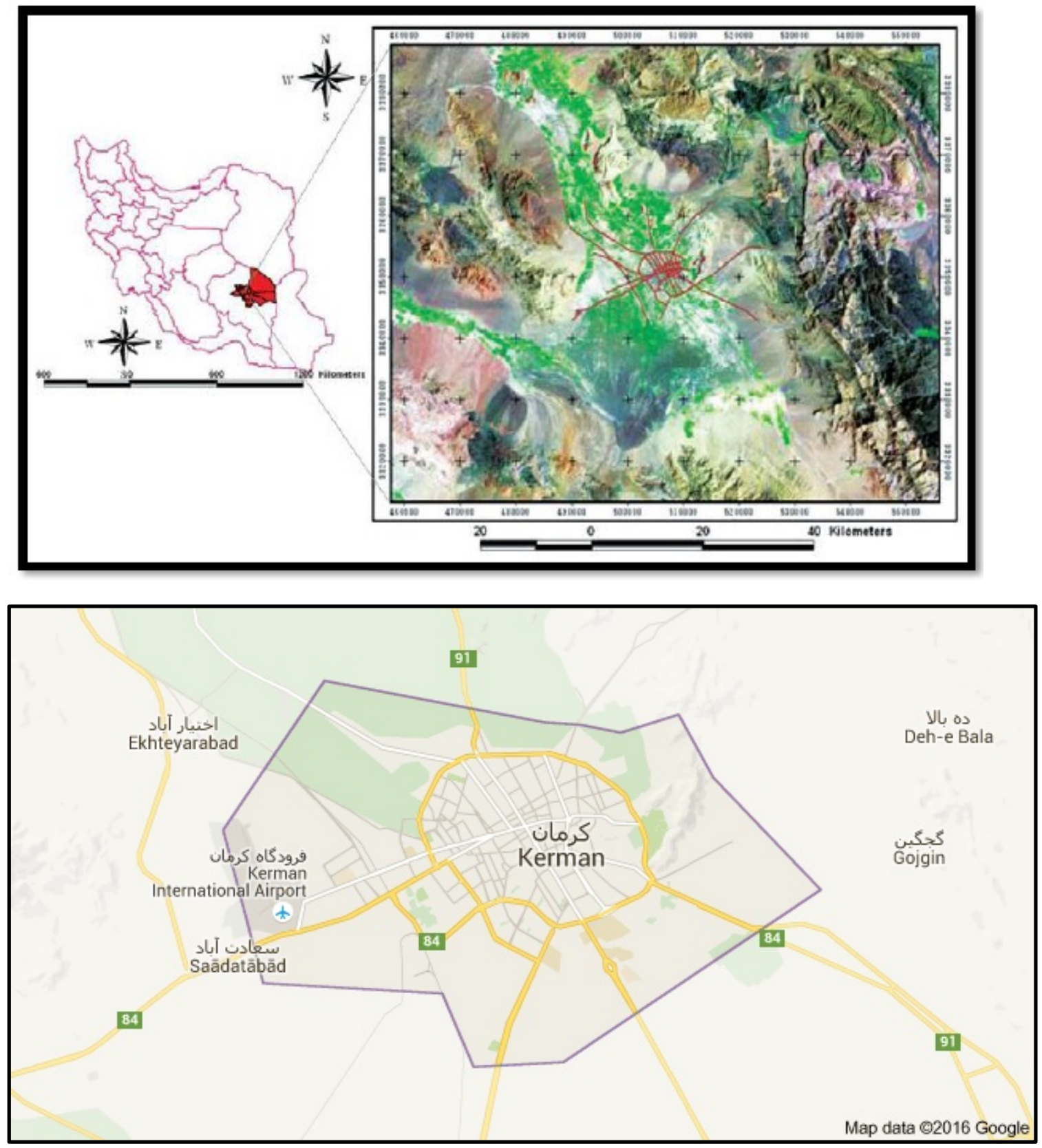

Figure 1. Geographical situation of Kerman city

\section{THE RESEARCH METHODOLOGY}

The present study in respect of objective is among applied studies and in regard of research method nature and its survey is a descriptive-analytical study. In this research, first regarding walkability indexes in walkability approach, pavements and those axles which have walkable capability were evaluated and then regarding criteria, locating was performed for finding the best axle using AHP method. For achieving the research objectives, library methods were used for recognizing components and criteria ( physical, social, economic and environmental) effective on walkability planning, then using field studies, qualitative and quantitative evaluation of available pavements and axles was done in district 2 of Kerman city. For data analysis and providing strategies of improving walkability SWOT analytical matrix was utilized. For this purpose, a list of strengths, weaknesses, opportunities and threats were identified and analyzed. The information relating to strengths, weaknesses, opportunities and threats was prepared from field perceptions in the mentioned region 
and after that by adjusting internal and external strategic factors which are the base of strategies codification, SWOT strategic matrix was extracted. The instrument used for creating database and producing respective maps is GIS geographic information system and for weighing criteria EXPORT CHOICE software was used.

\section{MAIN DISCUSSION:}

In this section of study, walking strategies were codified and desirability and limitations of district 2 of Kerman was analyzed using SWOT model which is explained here.

- Codifying walkability strategies of Kerman district 2

In framework of codifying strategies, the evaluation stage includes instruments which rely on information obtained from previous stages (evaluating internal and external environment) and external opportunities and threats are compared with internal strengths and weaknesses. The process of comparing internal and external factors plays a very significant and effective role. For this purpose, internal and external factors in matrix of threats, opportunities, strengths and weaknesses in each stage of two factors are compared with each other and the goal is not to recognize the best strategy, but it is to determine applicable strategies. Therefore, all strategies provided in this comparison, won't be selected and executed (table3).

Table3. SWOT the status dominated on walkability in Kerman district 2

\begin{tabular}{|c|c|c|c|}
\hline \multicolumn{2}{|l|}{ external conditions } & \multicolumn{2}{|l|}{ internal conditions } \\
\hline opportunities & threats & weaknesses & strengths \\
\hline $\begin{array}{l}\text { the possibility of reinforcing } \\
\text { presence and walking }\end{array}$ & $\begin{array}{lr}\text { lack of creating } & \text { spaces } \\
\text { proportionate } & \text { to } \\
\text { performance } & \end{array}$ & $\begin{array}{l}\text { the street defined } \\
\text { identity in citizens } \\
\text { mind due to } \\
\text { historical antiquity }\end{array}$ & $\begin{array}{l}\text { shortage of urban } \\
\text { elements } \\
\text { proportionate to the } \\
\text { range identity }\end{array}$ \\
\hline $\begin{array}{l}\text { continuity of walking routes in } \\
\text { short distances and those } \\
\text { spaces that motor vehicles can't } \\
\text { pass them }\end{array}$ & $\begin{array}{l}\text { ignoring passenger safety } \\
\text { and its non- priority in } \\
\text { traffic }\end{array}$ & $\begin{array}{l}\text { potential presence of } \\
\text { cultural acceptance } \\
\text { of walking } \\
\text { significance }\end{array}$ & $\begin{array}{l}\text { using poor materials } \\
\text { in urban furniture }\end{array}$ \\
\hline $\begin{array}{l}\text { reduction of activity and social } \\
\text { relations and people isolation } \\
\text { in limited space }\end{array}$ & $\begin{array}{l}\text { present potential for } \\
\text { creating and locating } \\
\text { identity making signs }\end{array}$ & $\begin{array}{l}\text { existence of } \\
\text { relatively suitable } \\
\text { infrastructures in the } \\
\text { range especially in } \\
\text { traffic ground }\end{array}$ & $\begin{array}{l}\text { inappropriate } \\
\text { locating of furniture } \\
\text { in the range length }\end{array}$ \\
\hline $\begin{array}{l}\text { great volume of people referral } \\
\text { and potential opportunity for } \\
\text { purchase, activity and walking }\end{array}$ & $\begin{array}{l}\text { non-definition of street as } \\
\text { commercial-recreational } \\
- \text { tourism axle in the } \\
\text { range level }\end{array}$ & $\begin{array}{l}\text { relative } \\
\text { adaptability }\end{array}$ & $\begin{array}{l}\text { limitation } \\
\text { relocation } \\
\text { people } \\
\text { disability }\end{array}$ \\
\hline $\begin{array}{l}\text { possibility of tradesmen } \\
\text { participation in reconstruction } \\
\text { plans and changing to walks } \\
\text { due to walkability history }\end{array}$ & lack of guiding top plan & uses variety & $\begin{array}{l}\text { intercurrence of cars } \\
\text { and passengers } \\
\text { movement }\end{array}$ \\
\hline $\begin{array}{lrr}\text { the possibility of } & \text { creating } \\
\text { massive space } & \text { and } \\
\text { administering } & & \text { special }\end{array}$ & $\begin{array}{l}\text { lack of welfare and } \\
\text { security for clients }\end{array}$ & $\begin{array}{l}\text { suitable wide and } \\
\text { length of the axle }\end{array}$ & $\begin{array}{l}\text { shortage of } \\
\text { recreational, cultural }\end{array}$ \\
\hline
\end{tabular}




\begin{tabular}{|c|c|c|c|}
\hline $\begin{array}{l}\text { periodical ceremonies relating } \\
\text { to culture and tradition in case } \\
\text { of creating special walk space }\end{array}$ & & for turning to walk & and public use \\
\hline $\begin{array}{l}\text { high volume of people traffic } \\
\text { causes creation of a live and } \\
\text { dynamic urban environment } \\
\text { during day and night }\end{array}$ & $\begin{array}{l}\text { noise pollution due to car } \\
\text { presence }\end{array}$ & $\begin{array}{lll}\text { suitable } & \text { slope for } \\
\text { walking } & & \end{array}$ & $\begin{array}{l}\text { limited time of uses } \\
\text { activity }\end{array}$ \\
\hline 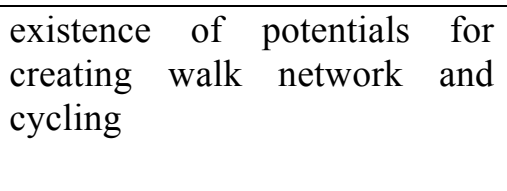 & $\begin{array}{l}\text { limitation of creating } \\
\text { open and public spaces } \\
\text { due to the land high value }\end{array}$ & $\begin{array}{l}\text { suitable access to } \\
\text { the span }\end{array}$ & $\begin{array}{l}\text { façade disorder and } \\
\text { lack of visual } \\
\text { quality of present } \\
\text { buildings }\end{array}$ \\
\hline $\begin{array}{l}\text { the possibility to develop } \\
\text { various uses and near to } \\
\text { standards for using facilities } \\
\text { for passengers as long as } \\
\text { presence of other facilities for } \\
\text { desirability of the environment }\end{array}$ & $\begin{array}{l}\text { lack of parking lot and } \\
\text { problems due to it for } \\
\text { people and tradesmen }\end{array}$ & $\begin{array}{l}\text { extreme density of } \\
\text { mass and shortage } \\
\text { of open and green } \\
\text { urban spaces }\end{array}$ & $\begin{array}{l}\text { designation of } \\
\text { commercial units to } \\
\text { sale of light } \\
\text { consumer goods and } \\
\text { as a result, lack of } \\
\text { producing heavy } \\
\text { garbage }\end{array}$ \\
\hline $\begin{array}{l}\text { reduction of air pollution and } \\
\text { reduction of fossil energies } \\
\text { consumption with people } \\
\text { encouragement for walking and } \\
\text { increasing public health } \\
\text { through it }\end{array}$ & $\begin{array}{llr}\text { physical } & \text { weakness } \text { for } \\
\text { creating } & \text { suitable social } \\
\text { relations } & & \end{array}$ & $\begin{array}{l}\text { referring to various } \\
\text { groups of people } \\
\text { and widespread } \\
\text { quantitative } \\
\text { presence of citizens }\end{array}$ & $\begin{array}{l}\text { lack of urban } \\
\text { furniture }\end{array}$ \\
\hline $\begin{array}{l}\text { existence of potential } \\
\text { walkability in the city } \\
\text { especially in center of city as } \\
\text { one of relocation system axles } \\
\text { of easy access to the } \\
\text { environment and competition } \\
\text { with suburb purchase centers }\end{array}$ & $\begin{array}{l}\text { sever lack of urban open } \\
\text { space }\end{array}$ & $\begin{array}{l}\text { existence of } \\
\text { population attractive } \\
\text { factors in the span }\end{array}$ & $\begin{array}{ll}\text { weakness of } & \text { social } \\
\text { activities } & \\
\text { qualitatively } & \text { and } \\
\text { quantitatively } & \end{array}$ \\
\hline $\begin{array}{l}\text { the possibility to revive } \\
\text { quarters and social life }\end{array}$ & $\begin{array}{l}\text { weakness of driving } \\
\text { culture and using cars } \\
\text { with single passenger by } \\
\text { most people }\end{array}$ & $\begin{array}{lr}\text { lack of } & \text { physical } \\
\text { obstacles } & \text { in } \\
\text { pavements of main } \\
\text { roads }\end{array}$ & $\begin{array}{l}\text { lack of accurate and } \\
\text { easy use of } \\
\text { environment and } \\
\text { uses due to traffic } \\
\text { problems }\end{array}$ \\
\hline $\begin{array}{l}\text { the possibility to increase } \\
\text { economic efficiency }\end{array}$ & $\begin{array}{l}\text { lack of regions special to } \\
\text { passenger quartering }\end{array}$ & $\begin{array}{l}\text { appropriateness of } \\
\text { pavements of crowd } \\
\text { routes in walking } \\
\text { span }\end{array}$ & $\begin{array}{l}\text { lack of suitable } \\
\text { lighting }\end{array}$ \\
\hline
\end{tabular}




\begin{tabular}{|c|c|c|c|}
\hline $\begin{array}{l}\text { reinforcement of local } \\
\text { movement network }\end{array}$ & $\begin{array}{l}\text { unfavorable quality of } \\
\text { some public } \\
\text { transportation systems } \\
\text { has caused people } \\
\text { dissatisfaction and their } \\
\text { usage is reduced }\end{array}$ & $\begin{array}{l}\text { implementation of } \\
\text { some plans of } \\
\text { managing traffic } \\
\text { like making the } \\
\text { streets one-sided }\end{array}$ & $\begin{array}{l}\text { lack of suitable } \\
\text { sanitary, security, } \\
\text { parking } \\
\text { residential facilities } \\
\text { appropriate to the } \\
\text { pan capacity }\end{array}$ \\
\hline $\begin{array}{l}\text { revival of urban spaces through } \\
\text { walkability for creating } \\
\text { massive memories }\end{array}$ & $\begin{array}{l}\text { lack of suitable culture } \\
\text { among drivers for } \\
\text { observing passengers and } \\
\text { cyclists rights }\end{array}$ & & \\
\hline $\begin{array}{l}\text { lack of much height difference } \\
\text { in physical texture }\end{array}$ & $\begin{array}{l}\text { lack of bridges and grade } \\
\text { separations for } \\
\text { passengers passing in the } \\
\text { span }\end{array}$ & \multirow[t]{2}{*}{$\begin{array}{l}\text { the possibility of } \\
\text { creating green } \\
\text { spaces in the span } \\
\text { and making green } \\
\text { spaces and parks }\end{array}$} & \multirow[t]{2}{*}{$\begin{array}{l}\text { existence of non- } \\
\text { identity urban spirit } \\
\text { at the end of the day } \\
\text { and shutting of } \\
\text { walks }\end{array}$} \\
\hline $\begin{array}{l}\text { existence of required } \\
\text { preparations for beautification } \\
\text { and preserving the available } \\
\text { and new-made pavements }\end{array}$ & $\begin{array}{l}\text { time shortage and haste } \\
\text { culture in the present era }\end{array}$ & & \\
\hline
\end{tabular}

Source: the author, based on field and documentary studies, 2016

Walking strategies of Kerman district 2, regarding various available structures, were codified during 6 stages using matrix of strengths, weaknesses, opportunities and threats. This matrix is one of very important instruments in the codification process of strategy by which the information of matrixes evaluating internal and external factors are compared with each other. By comparing opportunities and weaknesses, opportunity - threat strategies (SO) are obtained. In this same order, by comparing strengths and threats, strength- threat strategies ( ST), by comparing strengths and opportunities, weakness- opportunity strategies ( WO) and by comparing weaknesses and threats, weakness- threat strategies ( WT) are obtained. In this matrix, in each stage, two factors are compared with each other and the goal is not to recognize the best strategy, but the aim is to determine applicable strategies. After completion of matrix of strengths, weaknesses, opportunities and threats the following strategies were codified for walking in Kerman distract 2.

\section{Strength- opportunity strategies (SO)}

First strategy (SO1): The possibility to reinforce presence and walking through reinforcing suitable infrastructures in the span especially in the field of traffic, green space, etc. (S1, S4, O1)

Second strategy (SO2): Desirability in the environment with relative adaptability to uses and variety in it for encouraging various groups of people referral and widespread quantitative presence of citizens (S15, S7, S5, O4, O9).

Third strategy (SO3): The possibility of creating mass space and executing special periodical ceremony due to potential cultural acceptance of walking significance and population attractive people in the span $(\mathrm{S} 2, \mathrm{~S} 11, \mathrm{O} 6)$.

Fourth strategy (SO4): Traffic management in crowd axles and encouraging people for walking and increasing public health and vivacity in the span through it (S14, O7, S13, O10, O11). 
Sixth strategy (SO6): More participation of local societies in the plans of developing walking and the possibility of increasing economic and environmental efficiency through it (S9, O5, O12).

Seventh strategy (SO7): The possibility of quarter's massive revival with reinforcing local movement network and creating suitable and standard local access (S8, S6, O14, O12).

Eighth strategy (SO8): Assigning the span new roles such as tourism function regarding historical capabilities and plans of making walks (S1, O17, O2).

\section{strength- threat strategies (ST)}

Strategy 1: Creating required infrastructures for achieving the span walkability and reduction of pollutions due to in-city traffic (T7, S6, S13, S14).

Strategy 2: Necessity of preparing traffic plan for the span and also preforming traffic studies for specifying passages with high attraction of travel for designating that passages to walking $(\mathrm{S} 11, \mathrm{~S} 7, \mathrm{~T} 12, \mathrm{~T} 5, \mathrm{~T} 14)$.

Strategy 3: Cultural institutionalization of walking significance and rights of pedestrians by creating diverse programs in the span $(\mathrm{T} 2, \mathrm{~T} 15, \mathrm{~S} 2)$.

Strategy 4: Creating walking spaces in the span regarding existence of suitable conditions in it and predicting parking spaces with quartering limitation in the span (T9, T8, S4, S6).

Strategy 5: Creating suitable walking spaces regarding the conditions suitable for its creation and providing required instructions for citizens for promoting walking and cycling between people for reducing traffic in the city center and increasing people health (T17,T13,S8,S12,S14).

\section{Opportunity - weakness strategies (WO)}

Strategy 1: Widening pavement and creating cohesion in the span level and predicting people different needs (elderly, children and people with disability) (O8, O4, O1, W4, W10, W11)

Strategy 2: Creating required conditions for reducing conflicts and social inconsistencies inside the span (W2, W5, W12, O9, O12, and O15).

Strategy 3: Ereating pause spaces and spaces with identity for increasing social interactions $(\mathrm{O} 6, \mathrm{O} 3$, W15).

Strategy 4: Existence of required preparations for beautification of pavements and obviating required shortages for implementing the span ranges (W1, W6, W14, O17, O11).

Strategy 5: Reinforcing walking network through creating landscape and making suitable furniture for various ages and social classes for encouraging walking $(\mathrm{O} 16, \mathrm{O} 14, \mathrm{~W} 3, \mathrm{~W} 8)$.

\section{Weakness-threat strategies (WT)}

Strategy 1: Creating suitable and standard walkable infrastructures proportionate to the span conditions (W6, W1, T9, T16, W14, W11, W10).

Strategy 2: Creating suitable bed for social relations by physical reinforcement of the span (T10, W3, W8).

Strategy 3: Creating night life uses in the span and encouraging walking though it (W12, W13, W7, $\mathrm{T} 3, \mathrm{~T} 2, \mathrm{~T} 1)$.

Strategy 4: Creating safety and welfare for the society vulnerable people especially those with disability (T6, T13, W4). 
Strategy 5: Creating walkability spaces in the span and creating culture appropriate to drivers for observing rights of passengers and cyclists (T17, T15, T12, W15).

Strategy 6: Creating open urban spaces through encouraging participation of the span inhabitants for creating suitable spans of walkability (T8, T11, W9).

Strategy 7: Preparation and implementing plans of commercial, recreational and tourism axle in the span level for encouraging walkability (T4, T5, W2, W6).

\section{SELECTING ACCEPTABLE STRATEGIES OF WALKING IN KERMAN DISTRICT 2}

After codifying strategies by comparing internal and external factors in the matrix of strengths, weaknesses, opportunities and threats (SWOT), acceptable strategies are selected among these strategies. The situation of Kerman district 2 in the internal and external matrix determines acceptable strategies in walking. In case of locating in the first quarter of this matrix, aggressive- competitive strategies (SO) are used. In case of locating in the second quarter, revising strategies (WO), when locating in the third quarter, variety strategies (ST) and in case of locating in the fourth quarter, defensive strategies (WT) are used.

Table 4. SWOT matrix

\begin{tabular}{|l|l|l}
\hline internal - external factors & strengths (S) & weaknesses(W) \\
\hline Opportunities( O) & $\begin{array}{l}\text { Aggressive-competitive } \\
\text { strategies (SO) }\end{array}$ & Revising strategies (WO) \\
\hline Threats(T) & Variety strategies (SO) & Defensive strategies (WT) \\
\hline
\end{tabular}

Source: David, 2005:369

\section{ACCEPTABLE STRATEGIES OF WALKING IN KERMAN DISTRICT 2}

Acceptable strategies of walking in Kerman district 2, regarding the placement in the first quarter of internal and external matrix is aggressive strategies. For this reason, in the present conditions of this district internal development, SO strategies are emphasized and walking strategies of Kerman city district 2 regarding the considered structures is tending to the direction that using selected strategies, its various structures could reach a proper position in the city and district level besides realization of internal development in this district. This matrix is used for determining the span general status in strategic respect. This matrix has four main sockets. Surveys before preparing internal and external matrix provide the possibility of predicting the expected impacts of strategic decisions on the span. Internal and external matrix is divided to 4 major regions and for each of them various strategies are used. Regarding the performed calculations in internal and external evaluating matrix and numbers obtained from this matrix, two calculated numbers meeting and its establishment in each of four regions of acceptable strategies is used for walking in Kerman district 2.

\section{- Priority of acceptable strategies of walking in Kerman city district 2}

Decision making about acceptable walking strategies in Kerman city district 2 is performed using scientific analysis and intuitional judgment. In the previous stage by comparing internal and external factors, acceptable strategies were identified. In this stage, decisions are made about acceptable strategies. Attraction of each strategy is specified using qualitative strategic planning matrix and strategies with high attraction were selected as emphasized and prior strategies of walking in the district.

For determining priority of acceptable walking strategies in Kerman city region 2, we first form qualitative strategic planning matrix (QSPM). This matrix is used for determining the rate of attraction of codified strategies. Using this matrix could objectively specify various strategies which are among the best strategies. In the next stage, each internal and external factor which has a major 
role in Kerman city district 2 walking, a factor is given regarding their significance and they are placed in factors column. In the next stage, the attraction score of acceptable strategies is determined. Attraction scores are numerical rates which show attraction of each strategy in each series of strategies. For determining attraction score, internal and external factors which have a major role in Kerman city district 2 walking are examined and then this question is raised about each of them: does this factor have a major role in selection process of strategies? If the answer to this question is yes, then regarding these key factors, strategies are compared with each other and based on attraction score, a strategy relative significance comparing other strategies (regarding the discussed factor) is specified.

The attraction score is in this form: 1 - without attraction, $2=$ somewhat attractive, $3=$ with reasonable attraction and $4=$ very attractive. If the answer to the raised question is no, it indicates that in the process of selecting strategies this factor has no important role in Kerman city district 2 that in this case, attraction score shouldn't be given to this factor. The final score of attraction shows which strategy has the highest attraction. Finally, based on final score of attraction of Kerman city district 2 walking, priority of each strategy is determined.

Table 5. qualitative planning matrix (QSPM) - comparisons of internal matrix

\begin{tabular}{|c|c|c|c|c|c|c|c|c|c|c|c|c|c|c|c|c|c|}
\hline $\begin{array}{c}\infty \\
0 \\
0 \\
\vec{l} \\
\vec{R} \\
0\end{array}$ & B & 官 & is & $\begin{array}{r}0 \\
0 \\
0 \\
B \\
B\end{array}$ & is & $\frac{1}{n}$ & B & 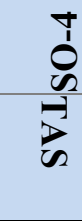 & is & $\begin{array}{l}\text { D̂} \\
\mathscr{6} \\
\vec{B} \\
\vec{B}\end{array}$ & B & $\frac{1}{o}$ & B & $\begin{array}{l}\overline{1} \\
0 \\
-1 \\
\text { D }\end{array}$ & s & $\begin{array}{l}\text { wei } \\
\text { ght }\end{array}$ & 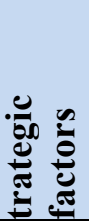 \\
\hline $\begin{array}{l}0.0 \\
96\end{array}$ & 4 & $\begin{array}{l}0.0 \\
72\end{array}$ & 3 & $\begin{array}{l}0.0 \\
72\end{array}$ & 3 & $\begin{array}{l}0.0 \\
48\end{array}$ & 2 & $\begin{array}{l}0.0 \\
96\end{array}$ & 4 & $\begin{array}{l}0.0 \\
72\end{array}$ & 3 & $\begin{array}{l}0.0 \\
84\end{array}$ & 3.5 & $\begin{array}{l}0.0 \\
72\end{array}$ & 3 & $\begin{array}{l}0.0 \\
24\end{array}$ & $1 \mathrm{~S}$ \\
\hline $\begin{array}{l}0.0 \\
58\end{array}$ & 2 & $\begin{array}{l}0.0 \\
87\end{array}$ & 3 & $\begin{array}{l}0.0 \\
87\end{array}$ & 3 & $\begin{array}{l}0.0 \\
58\end{array}$ & 2 & $\begin{array}{l}0.1 \\
16\end{array}$ & 4 & $\begin{array}{l}0.1 \\
02\end{array}$ & 3.5 & $\begin{array}{l}0.1 \\
02\end{array}$ & 3.5 & $\begin{array}{l}0.1 \\
16\end{array}$ & 4 & $\begin{array}{l}0.0 \\
29\end{array}$ & $2 \mathrm{~S}$ \\
\hline $\begin{array}{l}0.0 \\
84\end{array}$ & 3 & $\begin{array}{l}0.1 \\
12\end{array}$ & 4 & $\begin{array}{l}0.1 \\
12\end{array}$ & 4 & $\begin{array}{l}0.0 \\
84\end{array}$ & 3 & $\begin{array}{l}0.0 \\
84\end{array}$ & 3 & $\begin{array}{l}0.1 \\
12\end{array}$ & 4 & $\begin{array}{l}0.0 \\
84\end{array}$ & 3 & $\begin{array}{l}0.1 \\
12\end{array}$ & 4 & $\begin{array}{l}0.0 \\
28\end{array}$ & $3 \mathrm{~S}$ \\
\hline $\begin{array}{l}0.0 \\
8\end{array}$ & 2 & $\begin{array}{l}0.1 \\
2\end{array}$ & 3 & $\begin{array}{l}0.1 \\
2\end{array}$ & 3 & $\begin{array}{l}0.0 \\
8\end{array}$ & 2 & $\begin{array}{l}0.1 \\
2\end{array}$ & 3 & $\begin{array}{l}0.1 \\
4\end{array}$ & 3.5 & $\begin{array}{l}0.1 \\
6\end{array}$ & 4 & $\begin{array}{l}0.1 \\
2\end{array}$ & 3 & $\begin{array}{l}0.0 \\
4\end{array}$ & $4 \mathrm{~S}$ \\
\hline $\begin{array}{l}0.1 \\
17\end{array}$ & 3 & $\begin{array}{l}0.1 \\
17\end{array}$ & 3 & $\begin{array}{l}0.1 \\
56\end{array}$ & 4 & $\begin{array}{l}0.0 \\
78\end{array}$ & 2 & $\begin{array}{l}0.1 \\
17\end{array}$ & 3 & $\begin{array}{l}0.1 \\
56\end{array}$ & 4 & $\begin{array}{l}0.1 \\
56\end{array}$ & 4 & $\begin{array}{l}0.1 \\
37\end{array}$ & 3.5 & $\begin{array}{l}0.0 \\
39\end{array}$ & $5 \mathrm{~S}$ \\
\hline $\begin{array}{l}0.1 \\
56\end{array}$ & 4 & $\begin{array}{l}0.0 \\
78\end{array}$ & 2 & $\begin{array}{l}0.1 \\
17\end{array}$ & 3 & $\begin{array}{l}0.1 \\
17\end{array}$ & 3 & $\begin{array}{l}0.1 \\
17\end{array}$ & 3 & $\begin{array}{l}0.1 \\
56\end{array}$ & 4 & $\begin{array}{l}0.0 \\
78\end{array}$ & 2 & $\begin{array}{l}0.1 \\
17\end{array}$ & 3 & $\begin{array}{l}0.0 \\
39\end{array}$ & $6 \mathrm{~S}$ \\
\hline $\begin{array}{l}0.1 \\
2\end{array}$ & 3 & $\begin{array}{l}0.0 \\
8\end{array}$ & 2 & $\begin{array}{l}0.1 \\
2\end{array}$ & 3 & $\begin{array}{l}0.0 \\
8\end{array}$ & 2 & 0.1 & 2.5 & $\begin{array}{l}0.1 \\
6\end{array}$ & 4 & $\begin{array}{l}0.1 \\
6\end{array}$ & 4 & $\begin{array}{l}0.1 \\
6\end{array}$ & 4 & $\begin{array}{l}0.0 \\
4\end{array}$ & $7 \mathrm{~S}$ \\
\hline $\begin{array}{l}0.1 \\
08\end{array}$ & 3 & $\begin{array}{l}0.0 \\
72\end{array}$ & 2 & $\begin{array}{l}0.1 \\
08\end{array}$ & 3 & $\begin{array}{l}0.0 \\
72\end{array}$ & 2 & $\begin{array}{l}0.1 \\
08\end{array}$ & 3 & $\begin{array}{l}0.1 \\
08\end{array}$ & 3 & $\begin{array}{l}0.1 \\
08\end{array}$ & 3 & $\begin{array}{l}0.1 \\
26\end{array}$ & 3.5 & $\begin{array}{l}0.0 \\
36\end{array}$ & $8 \mathrm{~S}$ \\
\hline $\begin{array}{l}0.0 \\
7\end{array}$ & 2 & $\begin{array}{l}0.0 \\
7\end{array}$ & 2 & $\begin{array}{l}0.1 \\
05\end{array}$ & 3 & $\begin{array}{l}0.1 \\
05\end{array}$ & 3 & $\begin{array}{l}0.0 \\
88\end{array}$ & 2.5 & $\begin{array}{l}0.1 \\
23\end{array}$ & 3.5 & $\begin{array}{l}0.1 \\
05\end{array}$ & 3 & $\begin{array}{l}0.1 \\
05\end{array}$ & 3 & $\begin{array}{l}0.0 \\
35\end{array}$ & $9 \mathrm{~S}$ \\
\hline $\begin{array}{l}0.1 \\
14\end{array}$ & 3 & $\begin{array}{l}0.1 \\
14\end{array}$ & 3 & $\begin{array}{l}0.0 \\
95\end{array}$ & 2.5 & $\begin{array}{l}0.1 \\
14\end{array}$ & 3 & $\begin{array}{l}0.0 \\
76\end{array}$ & 2 & $\begin{array}{l}0.1 \\
33\end{array}$ & 3.5 & $\begin{array}{l}0.1 \\
14\end{array}$ & 3 & $\begin{array}{l}0.1 \\
14\end{array}$ & 3 & $\begin{array}{l}0.0 \\
38\end{array}$ & $10 \mathrm{~S}$ \\
\hline
\end{tabular}




\begin{tabular}{|c|c|c|c|c|c|c|c|c|c|c|c|c|c|c|c|c|c|}
\hline $\begin{array}{l}0.0 \\
68\end{array}$ & 2 & $\begin{array}{l}0.0 \\
68\end{array}$ & 2 & $\begin{array}{l}0.1 \\
02\end{array}$ & 3 & $\begin{array}{l}0.0 \\
68\end{array}$ & 2 & $\begin{array}{l}0.0 \\
68\end{array}$ & 2 & $\begin{array}{l}0.1 \\
19\end{array}$ & 3.5 & $\begin{array}{l}0.1 \\
36\end{array}$ & 4 & $\begin{array}{l}0.1 \\
02\end{array}$ & 3 & $\begin{array}{l}0.0 \\
34\end{array}$ & $11 \mathrm{~S}$ \\
\hline $\begin{array}{l}0.1 \\
11\end{array}$ & 3 & $\begin{array}{l}0.1 \\
11\end{array}$ & 3 & $\begin{array}{l}0.1 \\
48\end{array}$ & 4 & $\begin{array}{l}0.0 \\
74\end{array}$ & 2 & $\begin{array}{l}0.1 \\
11\end{array}$ & 3 & $\begin{array}{l}0.1 \\
48\end{array}$ & 4 & $\begin{array}{l}0.1 \\
48\end{array}$ & 4 & $\begin{array}{l}0.1 \\
48\end{array}$ & 4 & $\begin{array}{l}0.0 \\
37\end{array}$ & $12 \mathrm{~S}$ \\
\hline $\begin{array}{l}0.0 \\
9\end{array}$ & 3 & $\begin{array}{l}0.0 \\
6\end{array}$ & 2 & $\begin{array}{l}0.0 \\
9\end{array}$ & 3 & $\begin{array}{l}0.0 \\
6\end{array}$ & 2 & $\begin{array}{l}0.1 \\
2\end{array}$ & 4 & $\begin{array}{l}0.1 \\
2\end{array}$ & 4 & $\begin{array}{l}0.1 \\
2\end{array}$ & 4 & $\begin{array}{l}0.1 \\
2\end{array}$ & 4 & $\begin{array}{l}0.0 \\
3\end{array}$ & $13 \mathrm{~S}$ \\
\hline $\begin{array}{l}0.0 \\
76\end{array}$ & 2 & $\begin{array}{l}0.0 \\
76\end{array}$ & 2 & $\begin{array}{l}0.1 \\
14\end{array}$ & 3 & $\begin{array}{l}0.0 \\
38\end{array}$ & 1 & $\begin{array}{l}0.1 \\
14\end{array}$ & 3 & $\begin{array}{l}0.1 \\
33\end{array}$ & 3.5 & $\begin{array}{l}0.1 \\
14\end{array}$ & 3 & $\begin{array}{l}0.1 \\
33\end{array}$ & 3.5 & $\begin{array}{l}0.0 \\
38\end{array}$ & $14 \mathrm{~S}$ \\
\hline $\begin{array}{l}0.1 \\
16\end{array}$ & 4 & $\begin{array}{l}0.0 \\
87\end{array}$ & 3 & $\begin{array}{l}0.1 \\
16\end{array}$ & 4 & $\begin{array}{l}0.0 \\
87\end{array}$ & 3 & $\begin{array}{l}0.0 \\
87\end{array}$ & 3 & $\begin{array}{l}0.1 \\
16\end{array}$ & 4 & $\begin{array}{l}0.0 \\
87\end{array}$ & 3 & $\begin{array}{l}0.1 \\
16\end{array}$ & 4 & $\begin{array}{l}0.0 \\
29\end{array}$ & $15 \mathrm{~S}$ \\
\hline $\begin{array}{l}0.0 \\
5\end{array}$ & 2 & $\begin{array}{l}0.0 \\
75\end{array}$ & 3 & $\begin{array}{l}0.0 \\
75\end{array}$ & 3 & $\begin{array}{l}0.0 \\
75\end{array}$ & 3 & $\begin{array}{l}0.0 \\
75\end{array}$ & 3 & 0.1 & 4 & 0.1 & 4 & 0.1 & 4 & $\begin{array}{l}0.0 \\
25\end{array}$ & $1 \mathrm{~W}$ \\
\hline $\begin{array}{l}0.0 \\
54\end{array}$ & 2 & $\begin{array}{l}0.0 \\
81\end{array}$ & 3 & $\begin{array}{l}0.1 \\
08\end{array}$ & 4 & $\begin{array}{l}0.0 \\
81\end{array}$ & 3 & $\begin{array}{l}0.1 \\
08\end{array}$ & 4 & $\begin{array}{l}0.1 \\
08\end{array}$ & 4 & $\begin{array}{l}0.1 \\
08\end{array}$ & 4 & $\begin{array}{l}0.0 \\
95\end{array}$ & 3.5 & $\begin{array}{l}0.0 \\
27\end{array}$ & $2 \mathrm{~W}$ \\
\hline $\begin{array}{l}0.0 \\
93\end{array}$ & 3 & $\begin{array}{l}0.0 \\
62\end{array}$ & 2 & $\begin{array}{l}0.0 \\
93\end{array}$ & 3 & $\begin{array}{l}0.0 \\
62\end{array}$ & 2 & $\begin{array}{l}0.0 \\
62\end{array}$ & 2 & $\begin{array}{l}0.1 \\
24\end{array}$ & 4 & $\begin{array}{l}0.0 \\
93\end{array}$ & 3 & $\begin{array}{l}0.1 \\
09\end{array}$ & 3.5 & $\begin{array}{l}0.0 \\
31\end{array}$ & $3 \mathrm{~W}$ \\
\hline $\begin{array}{l}0.0 \\
99\end{array}$ & 3 & $\begin{array}{l}0.0 \\
66\end{array}$ & 2 & $\begin{array}{l}0.0 \\
99\end{array}$ & 3 & $\begin{array}{l}0.0 \\
33\end{array}$ & 1 & $\begin{array}{l}0.1 \\
32\end{array}$ & 4 & $\begin{array}{l}0.1 \\
32\end{array}$ & 4 & $\begin{array}{l}0.1 \\
16\end{array}$ & 3.5 & $\begin{array}{l}0.1 \\
32\end{array}$ & 4 & $\begin{array}{l}0.0 \\
33\end{array}$ & $4 \mathrm{~W}$ \\
\hline $\begin{array}{l}0.0 \\
96\end{array}$ & 4 & $\begin{array}{l}0.0 \\
48\end{array}$ & 2 & $\begin{array}{l}0.0 \\
96\end{array}$ & 4 & $\begin{array}{l}0.0 \\
72\end{array}$ & 3 & $\begin{array}{l}0.0 \\
72\end{array}$ & 3 & $\begin{array}{l}0.0 \\
72\end{array}$ & 3 & $\begin{array}{l}0.0 \\
72\end{array}$ & 3 & $\begin{array}{l}0.0 \\
96\end{array}$ & 4 & $\begin{array}{l}0.0 \\
24\end{array}$ & $5 \mathrm{~W}$ \\
\hline $\begin{array}{l}0.1 \\
14\end{array}$ & 3 & $\begin{array}{l}0.1 \\
14\end{array}$ & 3 & $\begin{array}{l}0.1 \\
14\end{array}$ & 3 & $\begin{array}{l}0.1 \\
14\end{array}$ & 3 & $\begin{array}{l}0.1 \\
14\end{array}$ & 3 & $\begin{array}{l}0.1 \\
14\end{array}$ & 3 & $\begin{array}{l}0.1 \\
14\end{array}$ & 3 & $\begin{array}{l}0.1 \\
52\end{array}$ & 4 & $\begin{array}{l}0.0 \\
38\end{array}$ & $6 \mathrm{~W}$ \\
\hline $\begin{array}{l}0.0 \\
99\end{array}$ & 3 & $\begin{array}{l}0.0 \\
99\end{array}$ & 3 & $\begin{array}{l}0.0 \\
99\end{array}$ & 3 & $\begin{array}{l}0.0 \\
99\end{array}$ & 3 & $\begin{array}{l}0.0 \\
99\end{array}$ & 3 & $\begin{array}{l}0.0 \\
99\end{array}$ & 3 & $\begin{array}{l}0.0 \\
99\end{array}$ & 3 & $\begin{array}{l}0.1 \\
32\end{array}$ & 4 & $\begin{array}{l}0.0 \\
33\end{array}$ & $7 \mathrm{~W}$ \\
\hline $\begin{array}{l}0.1 \\
6\end{array}$ & 4 & $\begin{array}{l}0.1 \\
2\end{array}$ & 3 & $\begin{array}{l}0.1 \\
6\end{array}$ & 4 & $\begin{array}{l}0.0 \\
4\end{array}$ & 1 & $\begin{array}{l}0.1 \\
2\end{array}$ & 3 & $\begin{array}{l}0.1 \\
2\end{array}$ & 3 & $\begin{array}{l}0.1 \\
6\end{array}$ & 4 & $\begin{array}{l}0.1 \\
2\end{array}$ & 3 & $\begin{array}{l}0.0 \\
4\end{array}$ & $8 \mathrm{~W}$ \\
\hline $\begin{array}{l}0.1 \\
14\end{array}$ & 3 & $\begin{array}{l}0.1 \\
14\end{array}$ & 3 & $\begin{array}{l}0.1 \\
14\end{array}$ & 3 & $\begin{array}{l}0.1 \\
52\end{array}$ & 4 & $\begin{array}{l}0.0 \\
76\end{array}$ & 2 & $\begin{array}{l}0.0 \\
76\end{array}$ & 2 & $\begin{array}{l}0.1 \\
33\end{array}$ & 3.5 & $\begin{array}{l}0.1 \\
14\end{array}$ & 3 & $\begin{array}{l}0.0 \\
38\end{array}$ & $9 \mathrm{~W}$ \\
\hline $\begin{array}{l}0.1 \\
2\end{array}$ & 3 & $\begin{array}{l}0.1 \\
2\end{array}$ & 3 & $\begin{array}{l}0.1 \\
2\end{array}$ & 3 & $\begin{array}{l}0.1 \\
6\end{array}$ & 4 & $\begin{array}{l}0.1 \\
2\end{array}$ & 3 & $\begin{array}{l}0.0 \\
8\end{array}$ & 2 & $\begin{array}{l}0.1 \\
2\end{array}$ & 3 & $\begin{array}{l}0.0 \\
8\end{array}$ & 2 & $\begin{array}{l}0.0 \\
4\end{array}$ & $10 \mathrm{~W}$ \\
\hline $\begin{array}{l}0.0 \\
74\end{array}$ & 2 & $\begin{array}{l}0.0 \\
74\end{array}$ & 2 & $\begin{array}{l}0.0 \\
93\end{array}$ & 2.5 & $\begin{array}{l}0.0 \\
74\end{array}$ & 2 & $\begin{array}{l}0.1 \\
11\end{array}$ & 3 & $\begin{array}{l}0.1 \\
3\end{array}$ & 3.5 & $\begin{array}{l}0.0 \\
74\end{array}$ & 2 & $\begin{array}{l}0.0 \\
74\end{array}$ & 2 & $\begin{array}{l}0.0 \\
37\end{array}$ & $11 \mathrm{~W}$ \\
\hline $\begin{array}{l}0.0 \\
64\end{array}$ & 2 & $\begin{array}{l}0.0 \\
96\end{array}$ & 3 & $\begin{array}{l}0.0 \\
96\end{array}$ & 3 & $\begin{array}{l}0.0 \\
64\end{array}$ & 2 & $\begin{array}{l}0.0 \\
8\end{array}$ & 2.5 & $\begin{array}{l}0.1 \\
12\end{array}$ & 3.5 & $\begin{array}{l}0.0 \\
96\end{array}$ & 3 & $\begin{array}{l}0.0 \\
8\end{array}$ & 2.5 & $\begin{array}{l}0.0 \\
32\end{array}$ & $12 \mathrm{~W}$ \\
\hline $\begin{array}{l}0.0 \\
78\end{array}$ & 3 & $\begin{array}{l}0.0 \\
52\end{array}$ & 2 & $\begin{array}{l}0.0 \\
78\end{array}$ & 3 & $\begin{array}{l}0.0 \\
52\end{array}$ & 2 & $\begin{array}{l}0.0 \\
65\end{array}$ & 2.5 & $\begin{array}{l}0.1 \\
04\end{array}$ & 4 & $\begin{array}{l}0.0 \\
78\end{array}$ & 3 & $\begin{array}{l}0.0 \\
78\end{array}$ & 3 & $\begin{array}{l}0.0 \\
26\end{array}$ & $13 \mathrm{~W}$ \\
\hline 0.0 & 3 & 0.0 & 2 & 0.0 & 3 & 0.0 & 2 & 0.0 & 3 & 0.1 & 4 & 0.0 & 3 & 0.1 & 4 & 0.0 & $14 \mathrm{~W}$ \\
\hline
\end{tabular}




\begin{tabular}{|l|l|l|l|l|l|l|l|l|l|l|l|l|l|l|l|l|l}
\hline 75 & & 5 & & 75 & & 5 & & 75 & & & & 75 & & & & 25 & \\
\hline $\begin{array}{l}0.1 \\
05\end{array}$ & 3 & $\begin{array}{l}0.0 \\
7\end{array}$ & 2 & $\begin{array}{l}0.1 \\
4\end{array}$ & 4 & $\begin{array}{l}0.0 \\
35\end{array}$ & 1 & $\begin{array}{l}0.1 \\
4\end{array}$ & 4 & $\begin{array}{l}0.1 \\
4\end{array}$ & 4 & $\begin{array}{l}0.1 \\
4\end{array}$ & 4 & $\begin{array}{l}0.1 \\
05\end{array}$ & 3 & $\begin{array}{l}0.0 \\
35\end{array}$ & $15 \mathrm{~W}$ \\
\hline $\begin{array}{l}2.8 \\
59\end{array}$ & 86 & $\begin{array}{l}2.5 \\
65\end{array}$ & 77 & $\begin{array}{l}3.2 \\
21 \\
5\end{array}$ & 97 & $\begin{array}{l}2.3 \\
26\end{array}$ & 70 & $\begin{array}{l}2.9 \\
70 \\
5\end{array}$ & 90 & $\begin{array}{l}3.5 \\
07 \\
5\end{array}$ & $\begin{array}{l}10 \\
6\end{array}$ & $\begin{array}{l}3.3 \\
33\end{array}$ & $\begin{array}{l}10 \\
0\end{array}$ & $\begin{array}{l}3.3 \\
63 \\
5\end{array}$ & $\begin{array}{l}10 \\
2\end{array}$ & 1 & \\
\hline
\end{tabular}

Source: author calculations

Table6. Qualitative planning matrix (QSPM) - external matrix comparisons

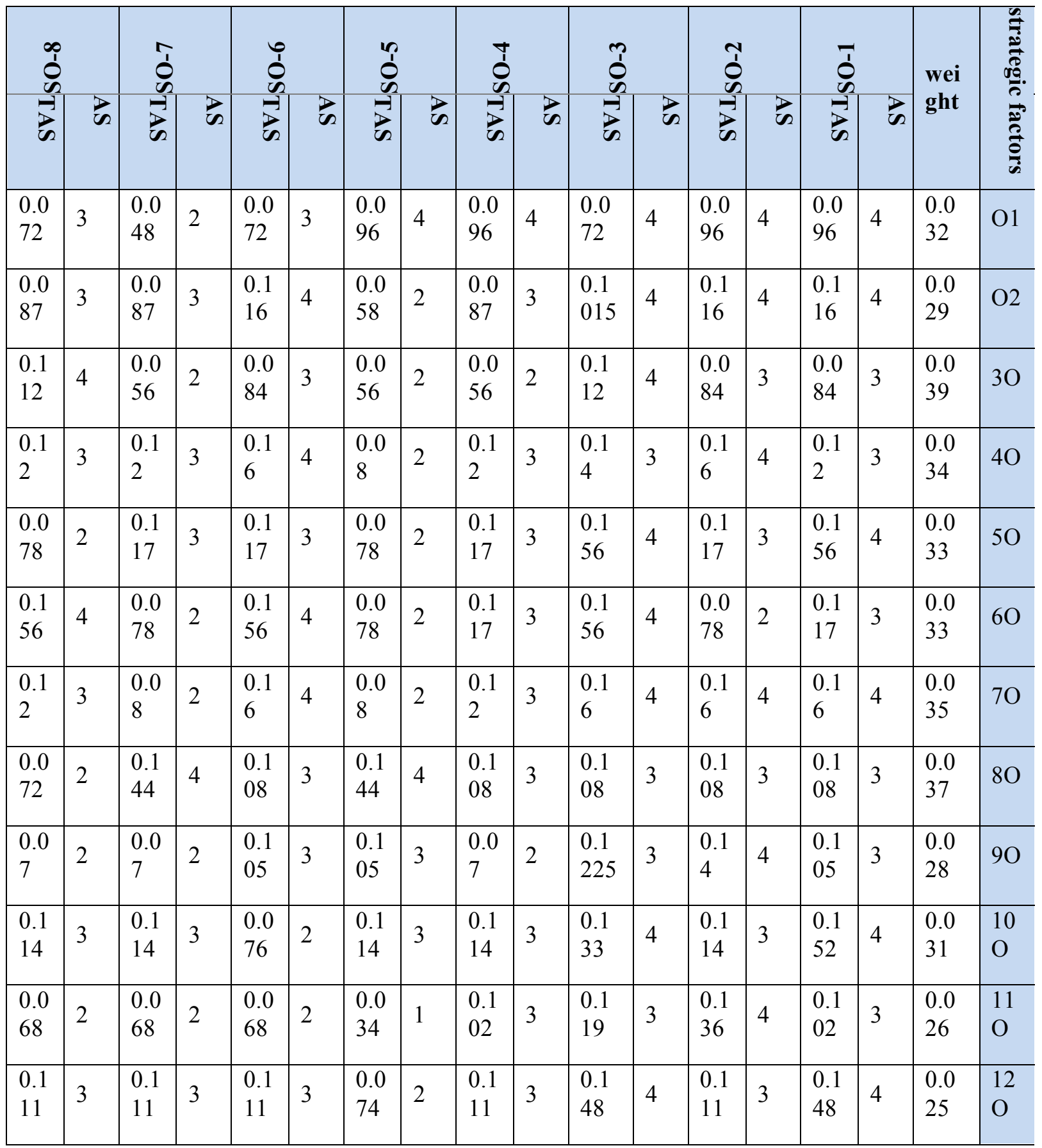




\begin{tabular}{|c|c|c|c|c|c|c|c|c|c|c|c|c|c|c|c|c|c|}
\hline $\begin{array}{l}0.0 \\
9\end{array}$ & 3 & $\begin{array}{l}0.1 \\
2\end{array}$ & 4 & $\begin{array}{l}0.1 \\
2\end{array}$ & 4 & $\begin{array}{l}0.1 \\
2\end{array}$ & 4 & $\begin{array}{l}0.1 \\
2\end{array}$ & 4 & $\begin{array}{l}0.1 \\
2\end{array}$ & 4 & $\begin{array}{l}0.1 \\
2\end{array}$ & 4 & $\begin{array}{l}0.0 \\
9\end{array}$ & 3 & $\begin{array}{l}0.0 \\
23\end{array}$ & $\begin{array}{l}13 \\
\mathrm{O}\end{array}$ \\
\hline $\begin{array}{l}0.0 \\
76\end{array}$ & 2 & $\begin{array}{l}0.0 \\
76\end{array}$ & 2 & $\begin{array}{l}0.1 \\
14\end{array}$ & 3 & $\begin{array}{l}0.0 \\
38\end{array}$ & 1 & $\begin{array}{l}0.0 \\
76\end{array}$ & 2 & $\begin{array}{l}0.1 \\
33\end{array}$ & 3 & $\begin{array}{l}0.1 \\
14\end{array}$ & 3 & $\begin{array}{l}0.1 \\
14\end{array}$ & 3 & $\begin{array}{l}0.0 \\
3\end{array}$ & $\begin{array}{l}14 \\
0\end{array}$ \\
\hline $\begin{array}{l}0.1 \\
16\end{array}$ & 4 & $\begin{array}{l}0.0 \\
87\end{array}$ & 3 & $\begin{array}{l}0.0 \\
87\end{array}$ & 3 & $\begin{array}{l}0.0 \\
87\end{array}$ & 3 & $\begin{array}{l}0.0 \\
87\end{array}$ & 3 & $\begin{array}{l}0.1 \\
16\end{array}$ & 4 & $\begin{array}{l}0.0 \\
87\end{array}$ & 3 & $\begin{array}{l}0.1 \\
16\end{array}$ & 4 & $\begin{array}{l}0.0 \\
2\end{array}$ & $\begin{array}{l}15 \\
O\end{array}$ \\
\hline $\begin{array}{l}0.0 \\
8\end{array}$ & 4 & $\begin{array}{l}0.0 \\
4\end{array}$ & 2 & $\begin{array}{l}0.0 \\
6\end{array}$ & 3 & $\begin{array}{l}0.0 \\
4\end{array}$ & 2 & $\begin{array}{l}0.0 \\
6\end{array}$ & 3 & 0.1 & 4 & $\begin{array}{l}0.0 \\
6\end{array}$ & 3 & $\begin{array}{l}0.0 \\
8\end{array}$ & 4 & $\begin{array}{l}0.0 \\
22\end{array}$ & $\begin{array}{l}16 \\
0\end{array}$ \\
\hline $\begin{array}{l}0.0 \\
44\end{array}$ & 4 & $\begin{array}{l}0.0 \\
22\end{array}$ & 2 & $\begin{array}{l}0.0 \\
44\end{array}$ & 4 & $\begin{array}{l}0.0 \\
33\end{array}$ & 3 & $\begin{array}{l}0.0 \\
22\end{array}$ & 2 & $\begin{array}{l}0.1 \\
08\end{array}$ & 4 & $\begin{array}{l}0.0 \\
33\end{array}$ & 3 & $\begin{array}{l}0.0 \\
44\end{array}$ & 4 & $\begin{array}{l}0.0 \\
19\end{array}$ & $\begin{array}{l}17 \\
\mathrm{O}\end{array}$ \\
\hline $\begin{array}{l}0.0 \\
5\end{array}$ & 2 & $\begin{array}{l}0.0 \\
75\end{array}$ & 3 & 0.1 & 4 & $\begin{array}{l}0.0 \\
5\end{array}$ & 2 & $\begin{array}{l}0.0 \\
75\end{array}$ & 3 & $\begin{array}{l}0.1 \\
24\end{array}$ & 4 & $\begin{array}{l}0.0 \\
75\end{array}$ & 3 & 0.1 & 4 & $\begin{array}{l}0.0 \\
28\end{array}$ & $1 \mathrm{~T}$ \\
\hline $\begin{array}{l}0.0 \\
54\end{array}$ & 2 & $\begin{array}{l}0.0 \\
81\end{array}$ & 3 & $\begin{array}{l}0.1 \\
08\end{array}$ & 4 & $\begin{array}{l}0.0 \\
27\end{array}$ & 1 & $\begin{array}{l}0.1 \\
08\end{array}$ & 4 & $\begin{array}{l}0.1 \\
32\end{array}$ & 4 & $\begin{array}{l}0.1 \\
08\end{array}$ & 4 & $\begin{array}{l}0.0 \\
81\end{array}$ & 3 & $\begin{array}{l}0.0 \\
31\end{array}$ & $2 \mathrm{~T}$ \\
\hline $\begin{array}{l}0.0 \\
62\end{array}$ & 2 & $\begin{array}{l}0.0 \\
62\end{array}$ & 2 & $\begin{array}{l}0.0 \\
62\end{array}$ & 2 & $\begin{array}{l}0.1 \\
24\end{array}$ & 4 & $\begin{array}{l}0.0 \\
93\end{array}$ & 3 & $\begin{array}{l}0.0 \\
72\end{array}$ & 3 & $\begin{array}{l}0.0 \\
93\end{array}$ & 3 & $\begin{array}{l}0.0 \\
93\end{array}$ & 3 & $\begin{array}{l}0.0 \\
32\end{array}$ & $3 \mathrm{~T}$ \\
\hline $\begin{array}{l}0.0 \\
66\end{array}$ & 2 & $\begin{array}{l}0.0 \\
66\end{array}$ & 2 & $\begin{array}{l}0.0 \\
99\end{array}$ & 3 & $\begin{array}{l}0.0 \\
33\end{array}$ & 1 & $\begin{array}{l}0.1 \\
32\end{array}$ & 4 & $\begin{array}{l}0.1 \\
14\end{array}$ & 4 & $\begin{array}{l}0.0 \\
99\end{array}$ & 3 & $\begin{array}{l}0.1 \\
32\end{array}$ & 4 & $\begin{array}{l}0.0 \\
38\end{array}$ & $4 \mathrm{~T}$ \\
\hline $\begin{array}{l}0.0 \\
96\end{array}$ & 4 & $\begin{array}{l}0.0 \\
48\end{array}$ & 2 & $\begin{array}{l}0.0 \\
96\end{array}$ & 4 & $\begin{array}{l}0.0 \\
24\end{array}$ & 1 & $\begin{array}{l}0.0 \\
72\end{array}$ & 3 & $\begin{array}{l}0.0 \\
99\end{array}$ & 3 & $\begin{array}{l}0.0 \\
96\end{array}$ & 4 & $\begin{array}{l}0.0 \\
96\end{array}$ & 4 & $\begin{array}{l}0.0 \\
3\end{array}$ & $5 \mathrm{~T}$ \\
\hline $\begin{array}{l}0.1 \\
14\end{array}$ & 3 & $\begin{array}{l}0.1 \\
14\end{array}$ & 3 & $\begin{array}{l}0.1 \\
14\end{array}$ & 3 & $\begin{array}{l}0.0 \\
76\end{array}$ & 2 & $\begin{array}{l}0.0 \\
76\end{array}$ & 2 & $\begin{array}{l}0.1 \\
2\end{array}$ & 3 & $\begin{array}{l}0.1 \\
14\end{array}$ & 3 & $\begin{array}{l}0.1 \\
52\end{array}$ & 4 & $\begin{array}{l}0.0 \\
33\end{array}$ & $6 \mathrm{~T}$ \\
\hline $\begin{array}{l}0.0 \\
99\end{array}$ & 3 & $\begin{array}{l}0.0 \\
99\end{array}$ & 3 & $\begin{array}{l}0.1 \\
32\end{array}$ & 4 & $\begin{array}{l}0.0 \\
99\end{array}$ & 3 & $\begin{array}{l}0.0 \\
99\end{array}$ & 3 & $\begin{array}{l}0.0 \\
76\end{array}$ & 4 & $\begin{array}{l}0.0 \\
99\end{array}$ & 3 & $\begin{array}{l}0.1 \\
32\end{array}$ & 4 & $\begin{array}{l}0.0 \\
37\end{array}$ & $7 \mathrm{~T}$ \\
\hline $\begin{array}{l}0.0 \\
8\end{array}$ & 2 & $\begin{array}{l}0.1 \\
2\end{array}$ & 3 & $\begin{array}{l}0.1 \\
6\end{array}$ & 4 & $\begin{array}{l}0.0 \\
4\end{array}$ & 1 & $\begin{array}{l}0.1 \\
2\end{array}$ & 3 & $\begin{array}{l}0.0 \\
8\end{array}$ & 3 & $\begin{array}{l}0.1 \\
6\end{array}$ & 4 & $\begin{array}{l}0.1 \\
6\end{array}$ & 4 & $\begin{array}{l}0.0 \\
35\end{array}$ & $8 \mathrm{~T}$ \\
\hline $\begin{array}{l}0.1 \\
14\end{array}$ & 3 & $\begin{array}{l}0.1 \\
14\end{array}$ & 3 & $\begin{array}{l}0.1 \\
14\end{array}$ & 3 & $\begin{array}{l}0.0 \\
76\end{array}$ & 2 & $\begin{array}{l}0.0 \\
76\end{array}$ & 2 & $\begin{array}{l}0.1 \\
295\end{array}$ & 4 & $\begin{array}{l}0.1 \\
14\end{array}$ & 3 & $\begin{array}{l}0.1 \\
52\end{array}$ & 4 & $\begin{array}{l}0.0 \\
29\end{array}$ & $9 \mathrm{~T}$ \\
\hline $\begin{array}{l}0.1 \\
2\end{array}$ & 3 & $\begin{array}{l}0.1 \\
2\end{array}$ & 3 & $\begin{array}{l}0.0 \\
8\end{array}$ & 2 & $\begin{array}{l}0.1 \\
6\end{array}$ & 4 & $\begin{array}{l}0.1 \\
2\end{array}$ & 3 & $\begin{array}{l}0.1 \\
12\end{array}$ & 2 & $\begin{array}{l}0.1 \\
6\end{array}$ & 4 & $\begin{array}{l}0.0 \\
8\end{array}$ & 2 & $\begin{array}{l}0.0 \\
34\end{array}$ & $\begin{array}{l}10 \\
\mathrm{~T}\end{array}$ \\
\hline $\begin{array}{l}0.0 \\
74\end{array}$ & 2 & $\begin{array}{l}0.0 \\
74\end{array}$ & 2 & $\begin{array}{l}0.0 \\
74\end{array}$ & 2 & $\begin{array}{l}0.1 \\
11\end{array}$ & 3 & $\begin{array}{l}0.1 \\
48\end{array}$ & 4 & $\begin{array}{l}0.1 \\
04\end{array}$ & 4 & $\begin{array}{l}0.1 \\
11\end{array}$ & 3 & $\begin{array}{l}0.0 \\
74\end{array}$ & 2 & $\begin{array}{l}0.0 \\
35\end{array}$ & $\begin{array}{l}11 \\
\mathrm{~T}\end{array}$ \\
\hline $\begin{array}{l}0.0 \\
64\end{array}$ & 2 & $\begin{array}{l}0.0 \\
96\end{array}$ & 3 & $\begin{array}{l}0.1 \\
28\end{array}$ & 4 & $\begin{array}{l}0.0 \\
64\end{array}$ & 2 & $\begin{array}{l}0.0 \\
64\end{array}$ & 2 & 0.1 & 3 & $\begin{array}{l}0.1 \\
28\end{array}$ & 4 & $\begin{array}{l}0.0 \\
96\end{array}$ & 3 & $\begin{array}{l}0.0 \\
36\end{array}$ & $\begin{array}{l}12 \\
\mathrm{~T}\end{array}$ \\
\hline $\begin{array}{l}0.0 \\
78\end{array}$ & 3 & $\begin{array}{l}0.0 \\
52\end{array}$ & 2 & $\begin{array}{l}0.0 \\
78\end{array}$ & 3 & $\begin{array}{l}0.0 \\
78\end{array}$ & 3 & $\begin{array}{l}0.0 \\
78\end{array}$ & 3 & $\begin{array}{l}0.1 \\
4\end{array}$ & 4 & $\begin{array}{l}0.0 \\
78\end{array}$ & 3 & $\begin{array}{l}0.1 \\
04\end{array}$ & 4 & $\begin{array}{l}0.0 \\
18\end{array}$ & $\begin{array}{l}13 \\
\mathrm{~T}\end{array}$ \\
\hline 0.0 & 2 & 0.0 & 2 & 0.0 & 2 & 0.0 & 2 & 0.0 & 2 & 0.1 & 4 & 0.1 & 4 & 0.1 & 4 & 0.0 & 14 \\
\hline
\end{tabular}




\begin{tabular}{|c|c|c|c|c|c|c|c|c|c|c|c|c|c|c|c|c|c|}
\hline 5 & & 5 & & 5 & & 5 & & 5 & & & & & & & & 23 & $\mathrm{~T}$ \\
\hline $\begin{array}{l}0.1 \\
05\end{array}$ & 3 & $\begin{array}{l}0.0 \\
7\end{array}$ & 2 & $\begin{array}{l}0.1 \\
4\end{array}$ & 4 & $\begin{array}{l}0.1 \\
4\end{array}$ & 4 & $\begin{array}{l}0.1 \\
4\end{array}$ & 4 & $\begin{array}{l}0.1 \\
4\end{array}$ & 4 & $\begin{array}{l}0.1 \\
4\end{array}$ & 4 & $\begin{array}{l}0.1 \\
05\end{array}$ & 3 & $\begin{array}{l}0.0 \\
22\end{array}$ & $\begin{array}{l}15 \\
\mathrm{~T}\end{array}$ \\
\hline $\begin{array}{l}0.1 \\
35\end{array}$ & 3 & $\begin{array}{l}0.0 \\
9\end{array}$ & 2 & $\begin{array}{l}0.0 \\
9\end{array}$ & 2 & $\begin{array}{l}0.0 \\
9\end{array}$ & 2 & $\begin{array}{l}0.1 \\
8\end{array}$ & 4 & $\begin{array}{l}0.1 \\
35\end{array}$ & 3 & $\begin{array}{l}0.1 \\
35\end{array}$ & 3 & $\begin{array}{l}0.1 \\
35\end{array}$ & 3 & $\begin{array}{l}0.0 \\
23\end{array}$ & $\begin{array}{l}16 \\
T\end{array}$ \\
\hline $\begin{array}{l}0.1 \\
65\end{array}$ & 3 & $\begin{array}{l}0.1 \\
1\end{array}$ & 2 & $\begin{array}{l}0.1 \\
65\end{array}$ & 3 & $\begin{array}{l}0.0 \\
55\end{array}$ & 1 & $\begin{array}{l}0.1 \\
65\end{array}$ & 3 & $\begin{array}{l}0.2 \\
2\end{array}$ & 4 & $\begin{array}{l}0.1 \\
65\end{array}$ & 3 & $\begin{array}{l}0.1 \\
65\end{array}$ & 3 & $\begin{array}{l}0.0 \\
2\end{array}$ & $\begin{array}{l}17 \\
\mathrm{~T}\end{array}$ \\
\hline $\begin{array}{l}3.1 \\
12\end{array}$ & 95 & $\begin{array}{l}2.8 \\
79\end{array}$ & 86 & $\begin{array}{l}3.5 \\
48\end{array}$ & $\begin{array}{l}10 \\
8\end{array}$ & $\begin{array}{l}2.6 \\
12\end{array}$ & 80 & $\begin{array}{l}3.3 \\
79\end{array}$ & $\begin{array}{l}10 \\
1\end{array}$ & $\begin{array}{l}4.1 \\
025\end{array}$ & $\begin{array}{l}12 \\
3\end{array}$ & $\begin{array}{l}3.8 \\
09\end{array}$ & $\begin{array}{l}11 \\
5\end{array}$ & $\begin{array}{l}3.8 \\
65\end{array}$ & $\begin{array}{l}11 \\
8\end{array}$ & 1 & \\
\hline
\end{tabular}

Source: author calculations

Based on performed calculations through QSPM matrix, total attraction final score of each strategy in Kerman city district 2 walking is as follows:

Table7. Final score of strategies attraction in Kerman city district 2 walking

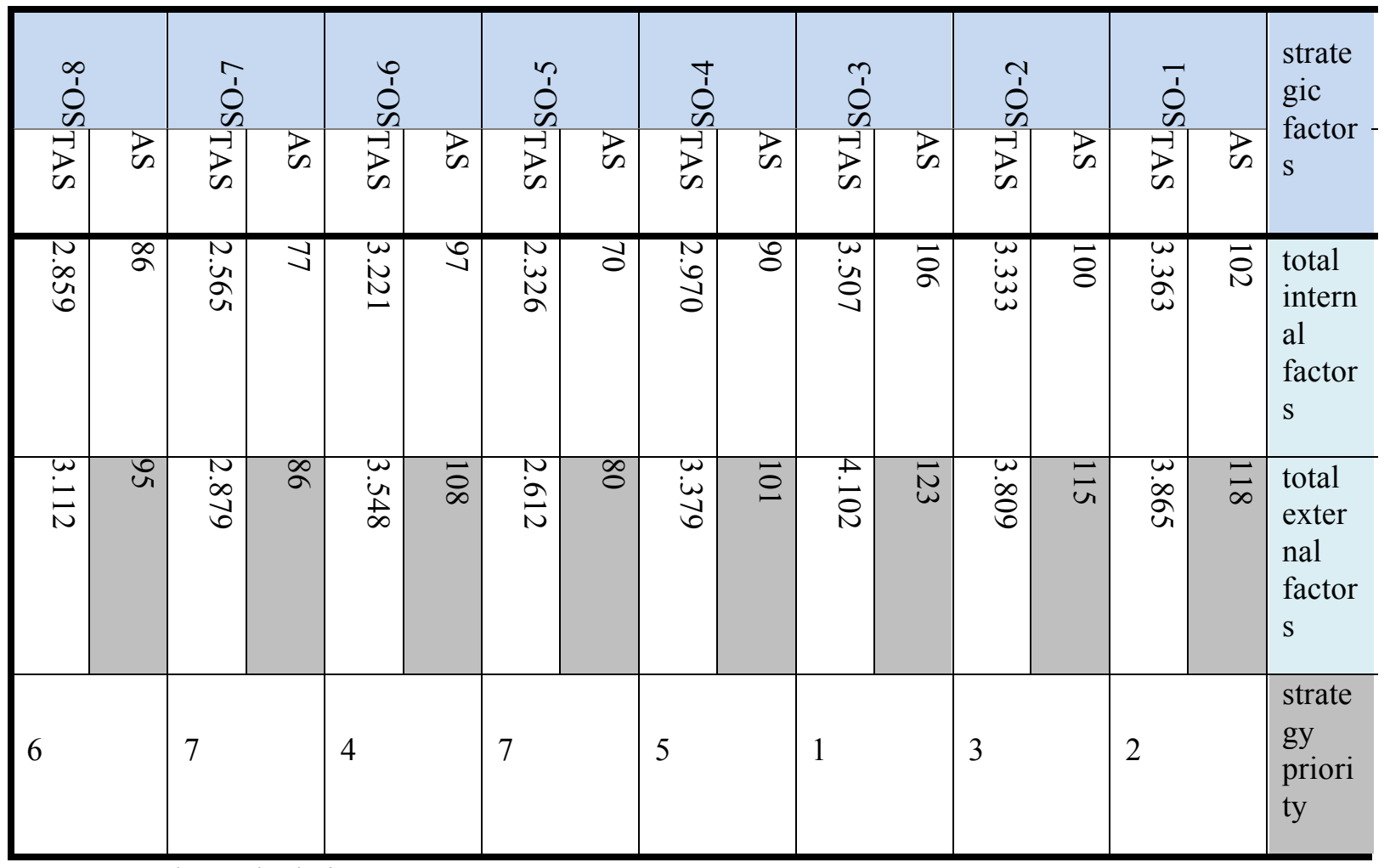

Source: author calculations, 2016

Regarding the performed calculations and matrix outputs (QSPM), determining priority of Kerman city district 2 walking strategies could be explained as follows:

Table8. Determining priority of Kerman city district 2 walking strategies

\begin{tabular}{|l|l|l}
\hline strategy & $\begin{array}{l}\text { final } \\
\text { attraction } \\
\text { score }\end{array}$ & $\begin{array}{l}\text { strategy } \\
\text { priority }\end{array}$ \\
\hline
\end{tabular}




\begin{tabular}{|c|c|c|c|}
\hline SO-1 & $\begin{array}{l}\text { The possibility of reinforcing presence and walking through } \\
\text { reinforcing suitable infrastructures in the span especially in } \\
\text { the field of traffic, green space, etc. }\end{array}$ & 3.865 & second \\
\hline SO-2 & $\begin{array}{l}\text { desirability in the environment with relative adaptability to } \\
\text { uses and variety in it for encouraging various groups of } \\
\text { people referral and widespread quantitative presence of } \\
\text { citizens }\end{array}$ & 3.809 & Third \\
\hline SO-3 & $\begin{array}{l}\text { the possibility of creating massive space and administering } \\
\text { special periodical ceremonies relating to culture and tradition } \\
\text { in case of creating special walk space }\end{array}$ & 4.1025 & first \\
\hline SO-4 & $\begin{array}{l}\text { traffic management in crowd axles and encouraging people } \\
\text { for walking and increasing public health and vivacity in the } \\
\text { span through it }\end{array}$ & 3.379 & fifth \\
\hline SO-5 & $\begin{array}{l}\text { reinforcing bicycle path and creating bicycle parking lot in } \\
\text { given distances regarding safe slope and lack of certain } \\
\text { physical obstacles }\end{array}$ & 2.612 & eighth \\
\hline SO-6 & $\begin{array}{l}\text { more participation of local societies in the plans of } \\
\text { developing walking and the possibility of increasing } \\
\text { economic and environmental efficiency through it }\end{array}$ & 3.548 & fourth \\
\hline SO-7 & $\begin{array}{l}\text { the possibility of quarters massive revival with reinforcing } \\
\text { local movement network and creating suitable and standard } \\
\text { local access }\end{array}$ & 2.879 & seventh \\
\hline SO-8 & $\begin{array}{l}\text { assigning the span new roles such as tourism function } \\
\text { regarding historical capabilities and plans of making walks }\end{array}$ & 3.112 & sixth \\
\hline
\end{tabular}

Source: author calculations, 2016

\section{CONCLUSION:}

Based on matrix of evaluation internal and external factors and also SWOT model, the final score relating to evaluating internal factors is equal to 2.986 and the final score of evaluating external factors is equal to 3.257. Regarding that the determined strategies type is determined according to final scores extracted from matrix of evaluating internal and external factors, according to the following figure, the fourfold strategies are as follows based on final scores:

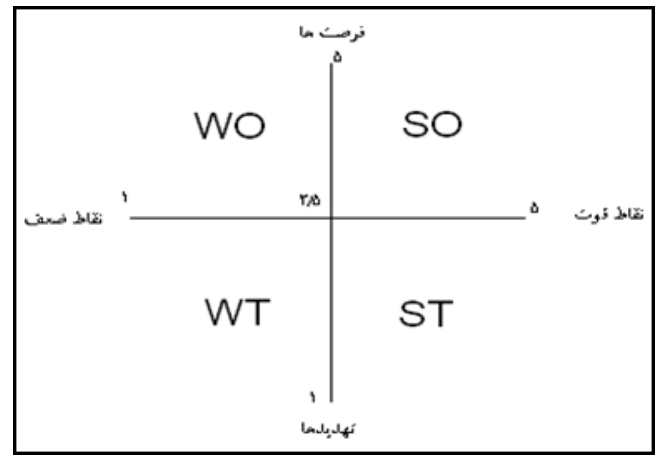

Figure 3. The position of acceptable strategies based on final score of internal and external factors 
On the other hand, as it was also pointed out in chapter 4 (figure 1-5), the situation of obtained scores from matrixes of evaluating internal and external factors is in the first quarter (aggressive strategy). So, regarding the above explanations, the dominant strategy in walkability of Kerman city district 2 is of aggressive type.

\section{REFERENCES}

John;king;Honory asla:landscap:Nov:2012:pp.78

Kacper:BIggosinksi:Justin:Helen:sf parkletmodular:1-90

Abley:s:(2005):Walkability:scoping:paper24-29

Jessica:Arnett: Impakt Studdy:Great street project:(2011)

Arora \& Burnet Avenue, Aveondale neighborhood: Revitalization Strategy.

Community walkability . In The principal of pedestrian network planning.

Fabian , H ., \&e. a. (2010). Walkability andpedestrain facilities in asian cities.

Bohl, C.(2000). New urbanism and the city : potential Applications and Implications for Distressed Inner-city Neighborhoods, housing policy debate 